Revue bibliographique pour le domaine irano-aryen

\title{
Michal Biran. "The Mongols in Central Asia from Chinggis Khan's invasion to the rise of Temür: the Ögödeid and Chaghadaid réal"
}

\section{Denise Aigle}

\section{(2) OpenEdition}

Journals

Édition électronique

URL : http://journals.openedition.org/abstractairanica/46397

DOI : 10.4000/abstractairanica.46397

ISBN : 1961-960X

ISSN : 1961-960X

Éditeur :

CNRS (UMR 7528 Mondes iraniens et indiens), Éditions de l'IFRI

\section{Référence électronique}

Denise Aigle, "Michal Biran. "The Mongols in Central Asia from Chinggis Khan's invasion to the rise of Temür: the Ögödeid and Chaghadaid réal" », Abstracta Iranica [En ligne], Volume 37-38-39 | 2018, document 2, mis en ligne le 30 décembre 2018, consulté le 29 septembre 2020. URL : http:// journals.openedition.org/abstractairanica/46397 ; DOI : https://doi.org/10.4000/abstractairanica. 46397

Ce document a été généré automatiquement le 29 septembre 2020.

Tous droits réservés 


\title{
Michal Biran. "The Mongols in Central Asia from Chinggis Khan's invasion to the rise of Temür: the Ögödeid and Chaghadaid réal"
}

\author{
Denise Aigle
}

\section{RÉFÉRENCE}

Michal Biran. "The Mongols in Central Asia from Chinggis Khan's invasion to the rise of Temür: the Ögödeid and Chaghadaid réal" in Nicola Di Cosmo, Allen J. Frank et Peter B. Golden (eds.). The Cambridge History of Inner Asia. The Chinggisid Age. Cambridge:

Cambridge University Press, $2015^{2}$, p. 46-66

1 La contribution de M. Biran s'intéresse à Qaidu (r. 1271-1301), le premier souverain mongol à avoir créé au XIV siècle un État indépendant en Asie centrale (voir son ouvrage, Qaidu and the Rise of the Independant Mongol State in Central Asia, Richemond, Curzon, 1977). Descendant de Ögödei, le successeur de Gengis Khan, Qaidu devint actif sur la scène politique, après l'intronisation de Tolui comme khaghan en 1251. Après la mort de Qaidu, les Chaghataides reprirent leur indépendance mais les sources à leur sujet sont peu nombreuses par rapport aux autres khanats. Néanmoins leur nom avait un certain prestige puisque les Turko-Mongols de Transoxiane ont continué à se désigner eux-mêmes comme ulus chaghatay, même sous Tamerlan et ses héritiers en Asie centrale. Par ailleurs, la littérature turke qui a fleurit dans la région à partir $\mathrm{du} \mathrm{Xv}^{\mathrm{e}}$ siècle fut aussi appelée chaghatay. 


\section{AUTEURS}

DENISE AIGLE

UMR 8167 - Orient et Méditerranée 